Article

\title{
Agricultural Productivity Growth and the Role of Capital in South Asia (1980-2013)
}

\author{
Asif Reza Anik 1,*, Sanzidur Rahman ${ }^{2}$ and Jaba Rani Sarker ${ }^{1}$ \\ 1 Department of Agricultural Economics, Faculty of Agricultural Economics and Rural Development, \\ Bangabandhu Sheikh Mujibur Rahman Agricultural University (BSMRAU), Gazipur 1706, Bangladesh; \\ jrsarker.aec@bsmrau.edu.bd \\ 2 School of Geography, Earth and Environmental Sciences, Faculty of Science and Engineering, \\ University of Plymouth, Plymouth PL4 8AA, UK; srahman@plymouth.ac.uk \\ * Correspondence: anikbd1979@gmail.com; Tel.: +880-17-644-74416
}

Academic Editor: Iain Gordon

Received: 12 December 2016; Accepted: 19 March 2017; Published: 21 March 2017

\begin{abstract}
The study assessed agricultural sustainability in South Asia (i.e., Bangladesh, Pakistan, India and Nepal) by computing multi-lateral multi-temporal Total Factor Productivity (TFP) indices and their six finer components (technical change, technical-, scale- and mix-efficiency changes, residual scale and residual mix-efficiency changes) and examined the role of capital in driving TFP growth covering a 34-year period (1980-2013). Results revealed that all countries sustained agricultural productivity growth at variable rates with Bangladesh experiencing highest rate estimated @1.05\% p.a. followed by India ( $0.52 \%)$, Pakistan $(0.38 \%)$ and Nepal ( $0.06 \%$ p.a.). There were little or no variation in technical and scale efficiency changes among the countries. However, residual scale efficiency increased @0.44\% p.a. in Bangladesh, 0.12\% p.a. in Pakistan, remained unchanged in India and declined $-0.39 \%$ p.a. in Nepal. Similarly, mix efficiency increased @0.44\% in Bangladesh, remained unchanged in India and declined @- $0.12 \%$ p.a.in Pakistan and $-0.39 \%$ p.a. in Nepal. The major drivers of agricultural TFP growth were the levels of natural, human and technology capital endowments whereas financial capital and crop diversification had opposite effects. Policy implications include land and tenurial reforms aimed at consolidating farm operation size and smooth operation of the land rental market to improve natural capital, investments in education to improve human capital and agricultural R\&D to enhance technology capital in order to boost agricultural productivity growth in South Asia.
\end{abstract}

Keywords: agricultural total factor productivity; technical-, scale- and mix-efficiency changes; technical change; natural; financial; human and technology capitals; South Asia

\section{Introduction}

Agriculture plays an important role in economic development, particularly in the developing economies of all regions. In addition to ensuring food and nutritional security, the sector does not only serve as the major source of rural employment and backbone of rural economies, but also contributes substantially to export earnings in developing economies. Following the food crisis and food price hike that the world experienced during 2008-2009, agriculture regained its importance in world politics and policy planners' priority list. The relative importance of agriculture is also high in South Asian countries, where one out of every three persons earns less than USD 1.25 per day, and the sector contributes significantly to GDP and serves as the major source of employment [1]. Agriculture contributes about 20\% to total GDP in Bangladesh, Bhutan, India and Pakistan [2-5] and 33.1\% in Nepal [6]. The agriculture sector employs about $50 \%$ of the total employment in Bangladesh, India 
and Pakistan [7], 31\% in Sri Lanka [8] and highest (65.6\%) in Nepal [6], hence demonstrating the importance of this sector in absorbing the growing labor force of these countries.

\subsection{Agricultural Growth and TFP: A Major Policy Objectives of the South Asian Countries}

To attain the desired level of agricultural growth, all the South Asian countries have emphasized the importance of TFP improvements in their subsequent plan documents. For example, the Twelfth Five Year Plan (2012-2017) of India, based on an examination of productivity of the three major agricultural inputs of land, labour and capital over the various plan periods, sought for especial focus on strategies to enhance TFP in agriculture [9]. Similarly, the 11th Five Year Plan of Pakistan (2013-2018) set a target of $4.0 \%$ to $5.0 \%$ agricultural growth to be achieved by improving TFP growth though technology-based interventions and minimizing yield gap [10]. The Approach Paper for the Thirteenth Plan (FY 2013/14-2015/16) prepared by the Government of Nepal also set objectives and operational strategies to increase productivity of crops and livestock products [11]. Nepal's Agricultural Development Strategy (2014) argued for TFP growth through enabling access to improved technologies and effective management of natural resources and other inputs [12]. Likewise, the Bangladesh Government's 7th Five Year Plan (FY 2016-2020) maintained its focus on enhancing agricultural TFP growth. The most crucial policy intervention mentioned for this goal is investment in research and development for technological innovations and measures to enhance labour productivity [13].

In line with the policies for improving agricultural growth, the selected South Asian countries continued to increase government spending in the agricultural sector as evidenced in Table 1. Compared to 2002-2004, not only expenditure in absolute term has increased but also the share of total outlays on agriculture has increased with some variations in between. For example, for India and Pakistan, both expenditures and share of total outlays in 2011-2013 are higher from its 2008-2010 level. In Bangladesh, India and Nepal, the central government's expenditure on agriculture have increased at an annual rate of $0.17 \%, 0.13 \%$ and $0.16 \%$, respectively. Similarly, agriculture's share of total outlays in Bangladesh, India and Nepal annually increased at a rate of $0.11 \%, 0.05 \%$ and $0.08 \%$, respectively. In Pakistan expenditure in both absolute and relative term remained constant. However, here one should bear in mind that increase in government expenditure do not always necessarily promote TFP, neither increase in agriculture's share of total outlays is always an indicator of TFP growth.

Table 1. Trend in Central Government Expenditure in Agriculture, Forestry and Fishing (Average of three years).

\begin{tabular}{ccccccccc}
\hline \multirow{2}{*}{ Year } & \multicolumn{3}{c}{ Value US\$, 2005 Prices } & \multicolumn{5}{c}{ Agriculture's Share of Total Outlays } \\
\cline { 2 - 8 } & Bangladesh & India & Pakistan & Nepal & Bangladesh & India & Pakistan & Nepal \\
\hline $2002-2004$ & 209.11 & 4862.50 & 198.54 & 60.78 & 3.64 & 4.35 & 1.19 & 5.21 \\
$2005-2007$ & 363.51 & 8396.34 & 567.58 & 74.13 & 5.46 & 5.86 & 2.56 & 5.76 \\
$2008-2010$ & 736.54 & 16131.50 & 1291.69 & 124.94 & 8.90 & 8.46 & 4.86 & 6.53 \\
$2011-2013$ & 971.14 & 14233.71 & 403.81 & 257.92 & 9.67 & 6.57 & 1.38 & 12.15 \\
\hline $\begin{array}{c}\text { Annual } \\
\text { Compound }\end{array}$ & $0.170^{* * *}$ & $0.126^{* * *}$ & 0.142 & $0.155^{* * *}$ & $0.108^{* * *}$ & 0.050 & 0.082 & $0.084^{* * *}$ \\
Growth Rate & & & & & & & 0.100 & 0.516 \\
\hline$R^{2}$ & 0.932 & 0.787 & 0.233 & 0.754 & 0.861 & 0.433 & 0.10 \\
\hline
\end{tabular}

Source: FAOSTAT. Note: For Bangladesh 2010 and 2011 data were missing. Linear trend method was applied to estimate expenditure for these two years. ${ }^{*}{ }^{* *}$ and ${ }^{* * *}$ indicate significant at $10 \%, 5 \%$ and $1 \%$ levels, respectively.

\subsection{The Green Revolution Technology and Agricultural Growth in South Asia}

Green Revolution (GR) technologies to drive agricultural growth were introduced in the region during the 1960s. The dominant feature of the technology was the use of high-yielding modern varieties of cereals (i.e., rice and wheat) and associated improved production practices (i.e., use of 
chemical fertilizers and pesticides, supplementary irrigation largely from ground water and sometimes from surface water sources and farm mechanization, etc.). Some proactive government policies in the form of input subsidy, pricing of inputs and outputs and investments in infrastructure, irrigation systems, research and extension, etc., paved the path towards achieving higher yields from scarce land resource base. Estimates based on the FAOSTAT data show that the South Asian countries (including Afghanistan) produced around 300\%-800\% more paddy and wheat in 2014 from their 1960 levels. This gain was possible due to increase in both land area and yield. For instance, paddy yields in Bangladesh, India, Nepal and Pakistan in 2014 were 2.6, 2.4, 1.8 and 1.7 times higher than those of 1961. During the same period, wheat yield in Bangladesh, India, Nepal and Pakistan increased by 5.5, 3.6, 2.0 and 3.4 times, respectively [14]. However, suspicion remains with respect to sustainability of the GR technology diffusion as gradual intensification of input use may end up with declining marginal returns [15]. For instance, Joshi et al. [16] found that in the Indo-Gangetic plain (IGP) of India, Total Factor Productivity (TFP) growth rates for rice and wheat were $2.08 \%$ and $2.14 \%$ p.a. respectively for the period 1990-99, which is lower than the earlier decade. In contrast, Rahman and Salim [17] reported that agricultural TFP changes fluctuated in the range of $1.30 \%$ to $1.38 \%$ p.a. during $2000-2008$ period in Bangladesh which was higher than the earlier decades and similar to growth rates estimated during the take-off stage of GR technology (i.e., 1960-1970). In this connection, there is now great concern about the potential for increasing productivity growth in the irrigated GR systems and its sustainability in the long run.

The two major sources of agricultural growth during the GR technology diffusion period in the region were the expansion of agricultural area and replacement of traditional varieties with modern varieties. However, over time the possibility of expanding agricultural area further is becoming limited or almost exhausted as the region is severely land constrained due to high population pressure. Moreover, the demand for land outside agriculture is increasing steadily. For instance, it is estimated that in Bangladesh, annually 1\% of the country's agricultural land is diverted to non-agricultural purposes [18]. Furthermore, as the countries have passed through the mature stage of the GR technology around three decades ago, it is quite unlikely to have ample scope for converting land under traditional varieties to modern varieties. Bera and Kelly [19] observed that such potential has almost been exhausted, as the ceiling adoption level of modern rice varieties appeared to have reached in Bangladesh. Simultaneously with increasing population, economic growth and urbanization demand for food is increasing and also consumption pattern is changing. In such a context, increasing productivity of the land and other inputs remains the most viable option for the region. Increased agricultural productivity can also contribute towards the growth of the non-agricultural sector by diverting scarce resources such as labor and capital outside agriculture [20].

\subsection{Total Factor Productivity and Agricultural Sustainability}

Total Factor Productivity (TFP) is a commonly used empirical tool to assess sustainability of a specific agricultural production system [21], or crops [22,23]. Any agricultural production system, whether extensive lower-yield or intensive higher yield, have significant ecological effects. Historically human dominated habitats including agricultural lands, were established by cleaning millions of hectares of forests and natural vegetation. This is still continuing and has little concern for preserving 'land for nature' [24]. Farming intensification has also resulted in degradation of the natural resource base, particularly soil and water, through overuse and mismanagement of different chemical inputs [25-27]. The situation may be exacerbated in the future as food production has to be increased, not only because the population is increasing, but also due to rising income, rapid urbanization and changes in consumption pattern [28-30]. The SDSN report [31] cited several cross-national examples to demonstrate that farmers' production gain was not necessarily associated with input intensification, rather through the increased efficiency of the use of chemical inputs, particularly nitrogen The report also noted significant gains in lowland irrigated rice yields in South America mainly due to strong public research and extension systems and science based agronomic management principles [31]. 
Wild biodiversity in agricultural landscapes can be effectively protected through enhanced research, policy coordination and planned support to agricultural communities and conservationists [24,32]. Braun [33] observed that agricultural growth does not necessarily result in environmental degradation, rather poverty can largely explain environmental degradation in rural areas of low income countries. He argued for appropriate technology design to mitigate specific health and nutrition risks associated with technological change. Effective pro-poor food policies and health interventions are prerequisite for sustainable agriculture and is also beneficial to the environment [33]. Literature also observed situations where population growth and poverty may offer both incentives and disincentives for land degradation [32,34]. The literature is in conclusive as to whether poverty in general induces farmers to manage their resources poorly in the long run [34].

Sustainability does not only have such biophysical dimension, which relates to use, preservation and enhancement of the long term productivity of the resource base, but also has economic and social dimensions [35], which are focus of our work. A major limiting factor for narrowing our focus to consider mainly economic and social dimension is the lack of cross-country time-series data on biophysical aspects of agriculture for South Asian countries under investigation. Furthermore, the economic viability of farming and rural communities in the long-term are the main issues in economic and social dimensions of sustainability [36]. While measuring sustainability, the biological and physical scientists focuses on crop yields on the output side, and include indicators of soil and water quality on the input side. Byerlee and Murgai [36] criticized such physical scientists' approach and noted that the yields have to be interpreted in relation to input use and that productivity is related to resource quality. Contrary to the approach adopted by the crop and soil scientists to analyse sustainability biophysically, the economists use the TFP approach, which is a single unambiguous measure of biophysical sustainability and explicitly accounts for changes in agricultural production in relation to changes in inputs [36]. Lynam and Herdt [37] argued for TFP analysis as an appropriate measure to determine sustainability, since in a sustainable production system, TFP should have a non-negative trend. Moreover, TFP indices capture the effect of technological improvements emanating from research and development activities and through investments made to develop infrastructures (e.g., irrigation, roads and electricity) [38]. Higher TFP ensures higher output from the use of modern technology and effective utilization of resources, thereby leading to poverty reduction, mainly in rural areas [39], which is one of the major policy objectives of the South Asian countries.

\subsection{Agricultural Productivity Growth Analysis for South Asia}

Studies on TFP growth and its determinants for the South Asian countries as a part of larger multi-country studies are available, though none conducted a cross-country comparison exclusively for the region. Cross-country comparison exclusively for South Asian region can be useful as these countries have similarities in terms of geography, production practices, farm characteristics and policies. The Indo-Gangetic plain, which includes Pakistan, India, Nepal, and Bangladesh, is the most fertile area in the region, supplying a lion's share of the region's food demand. Farming in the region is characterized by small farm holdings. For instance, in India and Bangladesh the average operated area is 1.15 ha [40] and 0.62 ha [41] respectively, with more than $85 \%$ of the farms are less than 1 ha in size. In Nepal the average farm size is 0.7 ha [42], whereas Pakistan has a much higher farm size estimated at 2.6 ha [43]. Agriculture in the region is dominated by cereals. The GR technology packages introduced in the South Asian countries were almost similar, mainly characterized by diffusion of high-yielding varieties (HYVs) of cereals (i.e., wheat and rice) along with the use of chemical fertilizers, insecticides, pesticides, supplementary irrigation and drainage and new methods of cultivation. All these were considered together as a 'package of practices' which is to be adopted as a whole to reap the full benefit of the GR technology. In this subcontinent after the end of British Colonial era, the general trend of cereal production was thought to have kept ahead of the population growth according to the official production figures. Much of the success was attributed to the combination of high propensity of investments in crop research, physical infrastructure, market as well as supply 
chain management development and appropriate policy support that took place during the first stage of GR period [44].

An extensive review of the available studies for the South Asian countries was done by Kumar et al. [45]. Coelli and Rao [46] explored FAO database and estimated TFP indices for 93 countries covering two decades (1980-2000). Among the South Asian countries, Bangladesh showed highest annual TFP growth rate (2.4\%), followed by Pakistan (2.3\%), India (1.4\%) and Nepal (1.0\%) [46]. Shahabinejad and Akbari [47] analyzed TFP growth for eight developing countries over the period of 1993-2007; in which Bangladesh and Pakistan exhibited of 0.7\% and 0.4\% growth rates respectively. Both Coelli and Rao [46] and Shahabinejad and Akbari [47] applied Data Envelopment Analysis (DEA) and estimated Malmquist productivity indices to drive technical efficiency, technological and TFP changes. Although Malmquist index is widely used in the literature, this index generally produces biased measure of TFP change except in cases when technology exhibits constant returns to scale (CRS) and inverse homotheticity [20,48-50]. Avila and Evenson [51] applied a 'simple accounting relationship derivation' to estimate agricultural TFP growth rates of developing countries and noted that TFP in Bangladesh, India, Pakistan, Nepal and Sri Lanka grew @0.65\%, 2.16\%, 1.86\%, 1.30\% and $-0.93 \%$ p.a. respectively, during the period 1961-2001. Similarly, Fuglie applied 'growth accounting' measure to estimate TFP for countries across different continents including seven South Asian countries (Afghanistan, Bangladesh, Bhutan, India, Pakistan, Nepal and Sri Lanka). For the region, the overall annual agricultural TFP grew by $0.63 \%, 0.86,1.31 \%, 1.22 \%$ and $1.96 \%$ during the periods $1961-70$, 1971-80, 1981-90, 1991-00 and 2001-09 respectively [52]. Both Avila and Evenson [51] and Fuglie [52] did not decompose TFP further to any of its associated efficiency measures and hence provided limited information on the drivers of growth.

Although all of the aforementioned studies provided important information on the levels of TFP growth in the region, there are a number of limitations to consider. First, they are part of multi-country comparisons where the reference frontier is at the global scale and therefore fails to account for differences in environmental production conditions, farming practices and policy environments of the South Asian region. Second, the indices are computed using simple index methods (i.e., Malmquist index, growth accounting, etc.), which are biased as they fail to satisfy transitivity as well as axioms of the index number theory [20,48-50]. Third, most of these multi-country studies did not decompose the components of TFP growth, which can shed light on the actual contributions of each of the associated efficiency measures to total TFP.

Therefore, given this backdrop, the main objectives of this study are to: (a) analyze agricultural TFP and associated efficiency measures for four South Asian countries (India, Pakistan, Bangladesh and Nepal) covering 34-year period (1980-2013); and (b) identify the role of different types of capital as drivers of TFP change.

The contributions of our study to the existing literature on agricultural productivity are as follows. First, we have adopted the Färe-Primont productivity index proposed by O'Donnell [50] to measure TFP, which circumvents all of the methodological weaknesses identified above. This is because the Färe-Primont index does not require assumptions about the nature of the production technology, behavior of the firms, structure of markets and information about returns to scale and/or input-output prices. The index also satisfies all important regularity conditions of index numbers, which includes conditions of multiplicative completeness and transitivity [50]. Second, we have extended our initiative to estimate six finer components of TFP (i.e., technical change, technical-efficiency, scale-efficiency, mix-efficiency, residual mix-efficiency and residual scale-efficiency changes) which is not available for the South Asian countries and also not common for even single country level studies except a few, such as Rahman and Salim for Bangladesh [17] and Temoso et al. for Botswana [53]. In addition, third, we use the framework of capital (i.e., technological, human, financial and natural capital) to examine their role in driving TFP growth for South Asian agriculture as the literature argue that several policy related variables including capital have significant impacts on TFP change $[17,46,51,54]$. 
The remaining of the paper is organized in three section. The following section presents the analytical framework and describes the data. The results are presented in Sections 3 and 4 discussions are done. Finally, in Section 5 conclusions and drawn and several policy implications are offered.

\section{Materials and Methods}

\subsection{The study Countries}

Although South Asia includes seven countries, all could not be included in this study. The present study focused on four countries: Bangladesh, India, Nepal and Pakistan which arguably has relatively higher level of dependence on agriculture. For example, Maldives is not considered as agriculture and mining together contributed only $1.8 \%$ of its GDP in 2012 [55]. Due to topography, Bhutan agriculture is characterized to be different than other countries and planning to rely preliminary on the use of organic materials [56-58] and the system has heavy reliance on traditional knowledge along with the avoidance of the use of chemicals in farming [58,59]. Besides, Government policy in Bhutan is to promote organic farming and all organic farms in the country enjoys tax holiday, in consistence to its target of becoming fully organic by 2020 [60]. On the other hand, though agriculture is important in Sri Lanka, it could not be included in the analysis largely due to unavailability of the reliable time-series data for the period under consideration.

\subsection{Analytical Framework: TFP Measurement}

To measure TFP and its six finer components for South Asian countries, we have adopted the recently developed Färe-Primont index (FPI), which is a non-parametric approach. As mentioned earlier, application of FPI and its associated six efficiency measures is not commonly seen in the earlier literature and was never applied to measure TFP in the South Asian context. Recently, to compute productivity indexes, two productivity indexes namely Hicks-Moorsteen index (HMI) and Färe-Primont index (FPI) are proposed by Bjurek [61] and O'Donnell [62], respectively. Both can compute TFP and do not require price data and do not impose any assumptions about the statistical noise. However, as HMI does not comply with the transitivity test, it is only be used for the purpose of single binary comparison; whereas the FPI can do multi-lateral and multi-temporal comparisons [62]. Stating differently, FPI is a suitable tool for comparing among many firms and many periods, which satisfies all other required regulatory conditions of an index (e.g., multiplicative completeness and transitivity test) [62].

The Färe-Primont index was developed using distance function as the aggregator function. The index can be decomposed into the product of technological progress, technical efficiency change, scale efficiency change and residual mix efficiency change. TFP change can also be decomposed into the components of technical change and TFP efficiency changes. TFP efficiency change can be further decomposed into technical, scale and mix efficiency changes. In this study, we employed this methodology proposed by O'Donnell $[48,62]$ which is summarized in the following section.

An index number is defined as a real number that measures the changes in a set of related variables [63]. Conceptually, index numbers may be used for comparisons over time or space or both. There are two main categories of index numbers: price index and quantity index numbers. The earlier category refers to consumer prices, input and output prices, export and import prices, etc.; whereas the latter category is concerned with changes in outputs produced or inputs used by a firm or industry over time or across firms [64]. The Färe-Primont TFP index is of the latter category and is based on two indices proposed by Färe and Primont [63]. As FPI is the ratio of an aggregate output to an aggregate input, we can express it through the following equation:

$$
T F P=\frac{Q(q)}{X(x)}
$$


By aggregating, the estimated outputs and inputs can be represented as follows [62]:

$$
\begin{aligned}
& Q(q)=D_{0}\left(x_{0}, q, t_{0}\right) \\
& X(x)=D_{1}\left(x, q_{0}, t_{0}\right)
\end{aligned}
$$

Given the production technology available in period $t$, Equations (2) and (3) are the Shepherd output and input distance functions, respectively [65]. Both the distance functions are characterized to be linearly homogenous, non-negative and non-decreasing. O'Donnell mentioned that the homogeneity and monotonicity properties make these functions natural candidates to be used as output and input aggregator functions [15]. Thus, the associated Färe-Primont index number for the TFP of the firm $i$ in $t$ period relative to the firm $h$ in $s$ period is [62]:

$$
T F P_{h s, j t}=\frac{D_{0}\left(x_{0}, q_{i t}, t_{0}\right) D_{1}\left(x_{h s}, q_{0}, t_{o}\right)}{D_{0}\left(x_{0}, q_{h s}, t_{0}\right) D_{1}\left(x_{i t}, q_{0}, t_{o}\right)}
$$

O'Donnell explained that, in a transitive index, the DPIN 3.0 software compares firm $i$ in period $t$ with firm 1 in period 1 . Most of the economic measures of efficiency, which are defined as ratio measures of TFP, are available in O'Donnell [62]. For example, O'Donnell showed the following output-oriented decompositions [50]:

$$
\begin{gathered}
T F P E_{n t}=O T E_{n t} \times O S E_{n t} \times R M E_{n t} \\
T F P E_{n t}=O T E_{n t} \times O M E_{n t} \times R O S E_{n t}
\end{gathered}
$$

where output-oriented technical efficiency (OTE) measures the shortfall in productivity of the firms operating below the production frontier [50], and the output oriented scale efficiency (OSE) and output-oriented mix efficiency (OME) measures account for shortfall in productivity due to diseconomies of scope. The residual output-oriented scale efficiency (ROSE) is defined as the ratio of TFP at a technically and mix-efficient point to the possible maximum TFP, and the residual mix efficiency (RME) is the component that remains after accounting for the effects of pure technical and pure scale efficiency changes [48].

\subsection{Estimation Using DEA}

Using the data envelopment analysis (DEA) linear programming (LP) method, DPIN 3.0 estimates the production technology along with the associated measures of productivity and efficiency [62]. The main assumption of using DEA method is that the (local) output distance functions representing the available technology in period $t$ takes the form [63]:

$$
D_{0}\left(x_{i t}, q_{i t}, t\right)=\left(q_{i t}^{\prime} \alpha\right) /\left(\gamma+x_{i t}^{\prime} \beta\right)
$$

The output-oriented problem involves finding the solutions for the unknown parameters in Equation (7) to minimize technical efficiency: OTE $E_{i t}^{-1}=D_{0}\left(x_{i t}, q_{i t}, t\right)^{-1}$. The resulting equation for the linear program is:

$$
D_{0}\left(x_{i t}, q_{i t}, t\right)^{-1}=O T E^{-1}=\min _{\alpha, \gamma, \beta}\left\{\gamma+x_{i t}^{\prime} \beta: \gamma l+X^{\prime} \beta \geq Q^{\prime} \alpha ; q_{i t}^{\prime} \alpha=1 ; \alpha \geq 0 ; \beta \geq 0\right\}
$$

where $Q$ is a $J \times M_{t}$ matrix of observed outputs, $X$ is a $K \times M_{t}$ matrix of observed inputs, $t$ is an $M_{t} \times 1$ unit vector, and $M t$ denotes the number of observations used to estimate the frontier in period $t$ [62]. 
The DPIN 3.0 uses an alternative type of this LP to compute productivity and efficiency indices. DPIN 3.0 first solves the following LP, to obtain the Färe-Primont aggregates [62]:

$$
D_{0}\left(x_{0}, q_{0}, t_{0}\right)^{-1}=\min _{\alpha, \gamma, \beta}\left\{\gamma+x_{0}^{\prime} \beta: \gamma l+X^{\prime} \beta \geq Q^{\prime} \alpha ; q_{0}^{\prime} \alpha=1 ; \alpha \geq 0 ; \beta \geq 0\right\}
$$

then the aggregated outputs and inputs of the Färe-Primont index can be obtained as [62]

$$
\begin{aligned}
& Q_{i t}=\left(q_{i t}^{\prime} \alpha_{0}\right) /\left(\gamma_{0}+x_{0}^{\prime} \beta_{0}\right) \\
& X_{i t}=\left(x_{i t}^{\prime} \eta_{0}\right) /\left(q_{0}^{\prime} \phi_{0}-\delta_{0}\right)
\end{aligned}
$$

where $\alpha_{0}, \beta_{0}, \phi_{0}$ and $\eta_{0}$ solve Equations (10) and (11). The DPIN 3.0 uses sample mean vectors as representative output and input vectors of the Equations (10) and (11). The representative technology here is obtained assuming no technical change thereby allowing the technology to exhibit variable returns to scale (VRS). When constant returns to scale (CRS) is assumed, DPIN 3.0 sets $\delta=0$ [62].

The description and estimation procedure of the variables used in the TFP analysis along with their data sources are presented below (in Table 2):

Table 2. Description of the variables used in the TFP analysis along with their data sources.

\begin{tabular}{ll}
\hline Outputs & \\
\hline & $\begin{array}{l}\text { Includes all seasons and varieties of cereals, roots and tubers, pulses, oilseeds, vegetables, } \\
\text { fruits and cash crops for all the four countries. Cereals, roots and tubers, and pulses are } \\
\text { measured in physical quantity (i.e., metric tons). For the other three outputs gross } \\
\text { production value (constant 2004-2006 1000 I\$) are calculated. We have used six output } \\
\text { variables namely: (i) cereals (including rice, wheat, barley, maize, millet, sorghum, etc.); } \\
\text { (ii) roots and tubers (includes Potatoes, sweet potatoes, cassava, etc.); pulses (all types, } \\
\text { e.g., broad and horse beans, different types of peas and beans, lentils, etc.); cash crops } \\
\text { (includes coffee, tea, tobacco, rubber, etc.); oilseed (all types, e.g., almonds, soybeans, } \\
\text { coconuts, groundnuts, rapeseed, sunflower seed, linseed, cashew nuts, sesame seed, } \\
\text { mustard seed etc.); and vegetable (all types, e.g., cabbages and other brassicas, tomatoes, } \\
\text { lettuce and chicory, pumpkins, squash, cauliflowers and broccoli, gourds, eggplants, } \\
\text { cucumbers and gherkins, green beans, carrots and turnips, okra, etc.) and fruits (apples, } \\
\text { bananas, oranges, lemons and limes, grapefruit, citrus fruit, pears, cherries, apricots, plums } \\
\text { and sloes, and peaches and nectarines, etc.). }\end{array}$ \\
\hline Inputs & \begin{tabular}{l} 
Number of total live draft animals (i.e., cattle and buffaloes) \\
\hline Animal power
\end{tabular} \\
\hline Labour & Total economically active population (000) working in agriculture \\
\hline Land area & $\begin{array}{l}\text { Land area is measured as gross cropped area derived by multiplying arable land (000 ha) } \\
\text { with cropping intensity (CI). The data for arable land and cropping intensity were taken } \\
\text { from faostat and respective country's national statistics, respectively. In Bangladesh, CI data } \\
\text { was missing for the years 1980, 2012 and 2013. For India and Pakistan, CI data was available } \\
\text { for the years 1990-2011. In Nepal CI information were available only for 1992, 2002 and 2012. } \\
\text { Standard linear trend interpolation method was applied for these missing information. } \\
\text { Similarly, for all the four countries, arable land data for the year 2013 is predicted. }\end{array}$ \\
\hline
\end{tabular}


Table 2. Cont.

\begin{tabular}{ll}
\hline Inputs & The proportion of land under irrigation is estimated as the ratio of total area equipped for \\
irrigation (000 ha) and gross cropped area (GCA). Data for the earlier variable is taken from \\
faostat. For all the country 2013 information was missing and is filled by interpolation method. \\
GCA is the product of arable land (000 ha) and cropping intensity (CI). CI data for Bangladesh \\
was collected from various issues of Year Book of Agricultural Statistics, 1983-1984, 1996, 2008, \\
2013 (BBS, various issues), whereas for Nepal data at only three points of time (1991/1992, \\
2001/2002 and 2011/2012) were available at the Pocket Book of Nepal, 2014 (CBS, 2014). \\
For India information about CI since 2000/01 is readily available at the Statistical Year Book \\
of India 2016, whereas for earlier years CI was calculated using information available at the \\
Handbook of Statistics on Indian Economy 2015-2016. Land utilization statistics (total cropped \\
area and net cropped area) for Pakistan since 1989/1990 were collected from Ministry of Food, \\
Agriculture and Livestock, Pakistan. The missing information were filled by interpolation or \\
extrapolation through simple linear trend method. \\
$\begin{array}{l}\text { Consumption of fertilizer in terms of total nutrients (metric tons) is estimated. Total nutrients } \\
\text { include nitrogen (N), potassium (K) and phosphorus (P) obtained from all types of fertilizers } \\
\text { (e.g., urea, single superphosphate, triple superphosphate, diammonium phosphate, muriate of } \\
\text { potash, etc.). For India, data for N, P and K consumption are taken from Agricultural Statistics } \\
\text { at a Glance 2010 and 2013. Fertilizer consumption data (in physical quantity) for Bangladesh, } \\
\text { are taken from the Year Book of Agricultural Statistics, 1983-1984, 1996, 2008, 2013 (BBS, } \\
\text { various issues), and then converted into actual nutrient ingredients. For few years after 2006, } \\
\text { some missing figures were replaced from Bangladesh Economic Review 2014. For Pakistan } \\
\text { and Nepal, nutrient consumption figures for the years 2002-2012 were available in faostat. } \\
\text { For the earlier years and 2013, a simple linear trend method is applied. }\end{array}$ \\
\hline Fertilizer
\end{tabular}

\subsection{Determinants of TFP Changes}

\subsubsection{Theoretical Framework}

The drivers of TFP change are estimated through a Dynamic Generalized Methods of Moment (GMM) estimator for panel data. Such a model is commonly used in analyzing panel dataset, particularly when there is endogeneity concerns [66]. In a situation where there are $N$ countries over $T$ periods, the TFP growth rate of the country $i$ in period $t$ can be written as [66]:

$$
\begin{gathered}
y_{i t}=\alpha_{0}+\sum_{e=1}^{m} \alpha_{e} y_{i, t-e}+\sum_{k=1}^{n} \sum_{j} \beta_{i j k} x_{i j, t-k}+\eta_{i}+u_{i t} \\
E\left(\eta_{i}\right)=E\left(u_{i}\right)=E\left(\eta_{i} u_{i t}\right)=0, i=1, \ldots, N ; t=1, \ldots, T
\end{gathered}
$$

where, $y_{i t}$ is the change in TFP index value for country $t$ in $i$ th year; $y_{i t}$ is the lag value of $y_{i t} ; x^{\prime}$ s are the different explanatory variables which may influence TFP change in $t-k$ period (the variables are described elaborately latter in this section); $\alpha$ and $\beta$ are the vectors of parameters to be estimated; $\eta_{i}$ is one of the orthogonal components of the error term capturing the stochastic individual effect, where the other component denoted by $u_{i t}$ is the idiosyncratic shock. Following Yu et al. we assume that the lag lengths $m$ and $n$ are sufficient to ensure that $u_{i t}$ is a stochastic error and $m$ equals $n$ [66]. The lag is included as a country's TFP growth is not only influenced by its current capital and resource endowments, rather previous years' TFP has a role in paving the path. A country can readjust input and budget allocation to attain higher level of TFP. A 'difference GMM' type of model allows us to capture such variations and also takes care of several econometric concerns including endogeneity and possible non-stationarity in panel data series. 


\subsubsection{Variables Explaining TFP Changes}

The available research identified several crucial policy level factors contributing to TFP growth. Of these some notable ones are: farm size, public and private research investments, extension expenditure, crop specialization, human capital, infrastructure (including roads, irrigation, power, etc.), vintage of capital, technology purchase expenditures, education, exposure or orientation to market, urbanization, etc. [17,54,67-69]. While analyzing trends in productivity growth, Byerlee and Murgai [36] suggested incorporating a wide range of variables such as conventional production inputs (land, labor, etc.) along with non-conventional inputs (education, infrastructure, etc.) and technology variables (e.g., high-yielding varieties, knowledge stock in the form of investment in research) and variables representing resource degradation (e.g., soil erosion, nutrient status, etc.), and weather variables. Avila and Evenson mentioned human, social and technological capital as factors influenced agricultural TFP performance in developing countries. They have constructed two new indexes named the Invention-Innovation Capital and Technology Mastery Capital to explain TFP growth. The Invention-Innovation Capital Index was constructed based on two indicators: agricultural scientists per unit of cropland and R\&D as a percentage of GDP, to measure the adaptive invention and innovative capacity [51]. Following Avila and Evenson [51], we have constructed the Technology Capital variable.

Based on the existing literature mentioned above, we have constructed five categories of explanatory variables to explain changes in TFP growth using the framework of capital endowment. These are: technology capital, mechanization level, human capital, financial capital, natural capital and the Herfindahl index of crop diversification. One may argue for variables relating to political and institutional factors (e.g., political stability, governance, institutional efficiency etc.) for explaining TFP growth. However, inclusion of such variables is always debatable and can be more biased than omitting those. Cross-country comparison among governance and institutional factors may not be always wise as there are socio-cultural dynamics. Furthermore, the available governance related cross-country indicators are mostly perception based, for instance the Corruption Perception Index prepared by the Transparency International, The definition and construction of these explanatory variables of TFP growth are as follows (in Table 3):

Table 3. Description of the explanatory variables used in explaining TFP changes along with their data sources.

\begin{tabular}{|c|c|}
\hline Variables & Description of variables \\
\hline Technology capital & $\begin{array}{l}\text { Using the information available in the faostat, this variable was constructed by adding the ratio of total } \\
\text { number of agricultural researchers (FTE) and gross cropped area with the agriculture research spending as } \\
\text { share of value added (agriculture, forestry and fishing). Simple linear inter and extrapolation methods were } \\
\text { employed to obtain data for the missing years. }\end{array}$ \\
\hline Mechanization level & $\begin{array}{l}\text { This variable was constructed by adding three indicators: } \\
\text { (a) Number of tractors available per GCA: The tractor numbers were collected from faostat. For Bangladesh } \\
\text { and Pakistan, data were available till 2006; whereas for India and Nepal data till } 2003 \text { and } 2008 \text { were available } \\
\text { respectively. The missing data points were filled through simple linear trend method. } \\
\text { (b) Agriculture and forestry energy use as a percentage of total energy use: The data for the period for } \\
\text { 1980-2009 were taken from faostat, whereas through linear trend method values for the later years } \\
\text { were predicted. } \\
\text { (c) Proportion of area equipped for irrigation is same as was used in estimating TFP and its components. }\end{array}$ \\
\hline Human capital & $\begin{array}{l}\text { Average year of schooling for the population was taken from the Human Capital Report } 2015 \text { of the World } \\
\text { Economic Forum [70]. }\end{array}$ \\
\hline Financial capital & $\begin{array}{l}\text { Development flows to agriculture from all donors (disbursement in USD } 2014 \text { prices) with the share of credit } \\
\text { to agriculture (including forestry and fishing) and total credit. Another component added here is the share of } \\
\text { agricultural GDP spend for agricultural science and technology. The data was taken from faostat, which are } \\
\text { available for different time periods for different countries. Interpolation method was applied to fill the } \\
\text { missing data. }\end{array}$ \\
\hline Natural capital & $\begin{array}{l}\text { The variable was constructed as the ratio of arable land (ha) and total population. The data was taken from } \\
\text { the faostat. }\end{array}$ \\
\hline $\begin{array}{l}\text { Herfindahl index of crop } \\
\text { diversification }\end{array}$ & $\begin{array}{l}\text { Herfindahl index of crop diversification (the value of the index is from } 0 \text { to } 1 \text { and higher value represents } \\
\text { specialization) is estimated through using information about land under different crops available at faostat. }\end{array}$ \\
\hline
\end{tabular}




\subsubsection{Econometric Issues}

There are econometric concerns with Equation (12), which provoked us to use the difference GMM method. For example, among the explanatory variables technology, i.e., capital, mechanization level, financial capital and the crop diversity index may have simultaneous causality problems with the dependent variable, resulting in these to be potentially endogenous. The GMM method can eliminate such problems of endogeneity [66]. Additionally, the lagged dependent variables might be endogenous to the individual effects in the error term in Equation (12). Inclusion of the lagged variable (i.e., change in TFP of the previous year, $y_{i, t-1}$ ) may cause autocorrelation problems [71]. To deal with such complexities, Arellano and Bond [72] proposed an estimation method of dynamic panel difference model using all suitably lagged endogenous (and predetermined) variables as instruments in the GMM technique. The method is known as the difference GMM. Equation (12) is transformed into a first-difference equation [66]:

$$
\triangle y_{i t}=\sum_{e=1}^{m} \alpha_{e} \triangle y_{i, t-e}+\sum_{k=1}^{n} \sum_{j} \beta_{i j k} \triangle x_{i j, t-k}+\triangle \eta_{i}+\triangle u_{i t}
$$

No correlation among the $u_{i t} s$ implies that the lagged dependent variableis uncorrelated with $\triangle y_{i t}$. In such instances, the lagged dependent variable works as valid instruments for difference Equation (13) at time $t+2$. By making full use of the conditional expectation of the product of the lagged dependent variable and all the moment equations, the GMM estimator addressing endogeneity and dynamic panel bias. The linear GMM estimators of parameter $\delta=(\alpha, \beta)^{\prime}$ are computed as [66]:

$$
\hat{\delta}=\left[\left(\sum_{i} W_{i}^{*} Z_{i}\right) A_{N}\left(\sum_{i} Z_{i}^{\prime} W_{i}^{*}\right)\right]^{-1} X\left[\left(\sum_{i} W_{i}^{*} Z_{i}\right) A_{N}\left(\sum_{i} Z_{i}^{\prime} Y_{i}^{*}\right)\right]
$$

where, $W_{i}^{*}=\left(\triangle y_{i}, \triangle x_{i}\right)$ is a data matrix containing the time series of the lagged differenced $y^{\prime} \mathrm{s}$ and $x^{\prime} s ; Z_{i}$ representing vector of instrumental variables, like lagged level of $y^{\prime} s$ and $x^{\prime}$ s and possibly other exogenous variables; the weighting matrix here is $A_{N}=\left(\frac{1}{N} \sum_{i} Z_{i}^{\prime} H_{i} Z_{i}\right)^{-1}$; and $H_{i}$ is a possibly individual specific covariance matrix of the transformed errors; $Y_{i}^{*}=\triangle y_{i}[66]$.

An important feature of the difference GMM is that it includes separate instruments for each time period. It does not make trade-off between instrument lag depth and sample depth in two-stage least square (2SLS). Furthermore, through adjusting for non-stationarity of the series, the differencing process results in consistent and asymptotically efficient estimators [66]. We use Roodman written 'xtabond2' program to estimate the parameters of the GMM model [73].

\section{Results}

\subsection{Summary Characteristics of the Study Regions}

Summary statistics of the variables used in determining TFP and all its components are presented in Table 4. India, the largest country in the region in terms of area, population and GDP; produced more than other three countries combined. Following India, Bangladesh comes next in cereal and roots \& tubers production; whereas Pakistan is ahead of Bangladesh and Nepal in the production of other four categories of outputs.

In input use, India leads with largest quantity of land, animal power, labour and fertilizer consumption. Compared to other three countries, Pakistan is more dependent on irrigation. Share of land equipped for irrigation is more than two times higher in Pakistan than other countries. In Bangladesh, relatively higher number of economically active population is involved with agriculture than in Pakistan and Nepal, though Gross Cropped Area is more in Pakistan than Bangladesh and Nepal. Pakistan has more cattle and buffalo stocks than Bangladesh and Nepal, and consumes more nutrients through fertilizer use than the two countries. 
Table 4. Major agricultural outputs and inputs for the South Asian countries, 1980-2013.

\begin{tabular}{lcccc}
\hline & Bangladesh & India & Pakistan & Nepal \\
\hline Outputs & & & & \\
Cereals (metric tons) & $34,232,352$ & $214,834,964$ & $26,185,959$ & $6,260,500$ \\
Roots and Tubers (metric tons) & $3,482,545$ & $29,450,091$ & $1,866,224$ & $1,302,632$ \\
Pulses (metric tons) & 423,922 & $13,507,441$ & 920,964 & 202,630 \\
Cash crops (gross production value, & 934,006 & $19,843,558$ & $4,452,873$ & 174,765 \\
constant 2004-2006 1000 USD) & & & & \\
Vegetables and fruits (gross & $1,076,900$ & $30,428,075$ & $2,465,146$ & 598,418 \\
production value, constant 2004-2006 & & & & \\
1000 USD) & 133,270 & $8,526,668$ & 323,120 & 84,532 \\
Oilseed (gross production value, & & & & \\
constant 2004-2006 1000 USD) & & & & \\
\hline Inputs & $23,627,865$ & $288,658,258$ & $43,794,114$ & $10,343,467$ \\
Cattle and buffaloes stocks (Head) & 31,109 & 227,204 & 18,293 & 7851 \\
Total economically active population & $1,456,162$ & $22,122,079$ & $2,868,725$ & 411,961 \\
in agriculture (1000) & $1,11,026$ & $15,088,612$ & $2,922,503$ & 24,847 \\
Gross cropped area & 0.2496 & 0.2493 & 0.6123 & 0.2473 \\
Fertilizer (Total Nutrient) & & & & 0.27 \\
Irrigation & 0.42 & 0.38 & 0.18 & 0.17 \\
\hline Determinants of TFP change & 3.52 & 4.82 & 2.19 & 2.17 \\
Technology capital & 3.55 & 3.76 & 3.16 & 0.58 \\
Mechanization level & 0.56 & 0.37 & 0.38 & \\
Human capital & 0.0289 & 0.0562 & 0.1428 & \\
Financial capital & 0.68 & 0.38 & 0.39 & \\
Natural capital & & & \\
Herfindahl index of crop & & & \\
diversification & & & \\
\hline Source Mainly computed from & & & \\
\hline
\end{tabular}

Source: Mainly computed from FAOSTAT. Cropping intensity data to calculate gross cropped area were taken from respective country statistics. Indian fertilizer data are collected from the Agricultural Statistics at a Glance 2010 and 2013; whereas fertilizer data for Bangladesh are taken from the various issues of Year Book of Agricultural Statistics. Data for adult literacy rate are taken from World Bank's website. Please refer to Section 2.4 for more detailed description of the data sources.

\subsection{Agricultural Productivity Growth and Associated Efficiency Changes}

Table 5 presents the Färe-Primont index estimates of TFP levels and their components for the selected four South Asian countries. The average TFP level during the study period was highest in Pakistan (0.91), followed by India (0.85), Nepal (0.67) and Bangladesh (0.65), respectively. All the four countries experienced nearly unitary technical, scale and mix efficiency levels (Table 5).

Table 5. Total factor productivity and efficiency levels (Geometric means 1980-2013).

\begin{tabular}{ccccccccc}
\hline Countries & $\begin{array}{c}\text { TFP } \\
\text { Level }\end{array}$ & $\begin{array}{c}\text { Maximum } \\
\text { TFP } \\
\text { Level }\end{array}$ & $\begin{array}{c}\text { TFP } \\
\text { Efficiency } \\
\text { Level }\end{array}$ & $\begin{array}{c}\text { Technical } \\
\text { Efficiency } \\
\text { Level }\end{array}$ & $\begin{array}{c}\text { Scale } \\
\text { Efficiency } \\
\text { Level }\end{array}$ & $\begin{array}{c}\text { Mix } \\
\text { Efficiency } \\
\text { Level }\end{array}$ & $\begin{array}{c}\text { Residual } \\
\text { Scale } \\
\text { Efficiency } \\
\text { Level }\end{array}$ & $\begin{array}{c}\text { Residual } \\
\text { Mix } \\
\text { Efficiency } \\
\text { Level }\end{array}$ \\
\hline Bangladesh & 0.65 & 0.91 & 0.72 & 1.00 & 1.00 & 1.00 & 0.72 & 0.72 \\
India & 0.85 & 0.91 & 0.94 & 1.00 & 1.00 & 0.99 & 0.95 & 0.94 \\
Nepal & 0.67 & 0.91 & 0.74 & 1.00 & 1.00 & 0.99 & 0.75 & 0.74 \\
Pakistan & 0.91 & 0.87 & 0.87 & 0.99 & 1.00 & 0.97 & 0.90 & 0.87 \\
\hline
\end{tabular}

Changes in TFP and its six finer components for the selected years and over periods are presented in Table 6. In the region, Bangladesh has experienced highest TFP growth rate estimated at $1.05 \%$ p.a. Coelli and Rao [46] also observed relatively higher TFP growth rate for Bangladesh compared to India, Nepal and Pakistan. We found negative growth rate $(-0.60 \%)$ during the first decade under 
consideration (i.e., 1981-1990), whereas growth rates during 1990-2000 and 2001-2013 were 1.71\% and $2.44 \%$, respectively. Fuglie's study using FAO data reported similar trend in TFP growth rate for Bangladesh. He reported that TFP in Bangladesh grew @-0.51\%, 2.12 and 3.31\% p.a. during the periods 1981-1990, 1991-2000 and 2001-2009, respectively [52]. Two explanations can be offered for differences in growth rates between ours and Fuglie's. Firstly, though both studies explored FAO database, there are differences in period covered and items covered for inputs and outputs. Fuglie covered more commodities in constructing outputs including livestock. There are also differences in the list of inputs. Secondly, Fuglie applied the "growth accounting" approach across a broad set of countries given data on production outputs, inputs, and their economic values.

In Bangladesh, the growth patterns for residual scale and mix efficiency growth are similar as that of the TFP growth. However, the country has experienced no change in technical, scale and mix efficiency during the periods under consideration. According to Rahman and Salim, technological progress was the major driver for TFP growth in Bangladesh agriculture during 1948-2008, whereas technical efficiency improvement had negligible contribution. They estimated negligible decline in scale efficiency $(-0.01 \%$ p.a.), but high $(-0.19 \%$ p.a.) decline in mix efficiency [17]. Our estimated TFP growth rate is higher than are recorded in earlier studies for Bangladesh [17,74-77]. For instance, through Färe-Primont index, Rahman and Salim [17] estimated $0.57 \%$ annual growth rate over six decades. Our estimated growth rate for Bangladesh is comparable with Dey and Evenson [75] and Rahman [77] who reported $0.94 \%$ and $0.90 \%$ annual growth rate respectively. The estimated higher growth rate may be related with the time periods covered. All the previous studies covered periods prior to 1980s, when the country was at the early stage of GR and was experiencing lower TFP growth rate with a fluctuating cycle. The growth rate took upward trend during post-GR period, particularly from 1985 [77]. Avila and Evenson [51] also reported that the crop sector in Bangladesh experienced negative annual growth rate $(-0.23 \%)$ during the period $1961-80$, but in the following two decades (1981-1901) grew at a rate of $1.06 \%$ p.a.

The estimated growth rate for Indian agriculture (0.52\% p.a.) is lower than reported in earlier studies $[16,46,51,54,78]$. Evenson et al. [68] estimated TFP growth rate in Indian crop sector since 1956 ranging from $1.05 \%$ to $1.39 \%$ p.a. For crops and livestock sector, Fan et al. [54] reported annual TFP growth rate of 1.75\% during the period 1970-1994; whereas Coelli and Rao [64] reported 0.90\% p.a. TFP growth rate during the last two decades of the previous century. Avila and Evenson reported $1.54 \%$ p.a. TFP growth rate for the crop sector during 1961-1980, which further accelerated to $2.33 \%$ p.a. in the following two decades. Fluctuation exist in the pattern of growth rate. In India, the estimated growth rates during $1981-1990,1991-2000$ and $2001-2013$ are $0.17 \%,-0.60 \%$ and $0.85 \%$ p.a. respectively [51]. According to Fuglie [52] in Indian agriculture TFP growth rates for the periods 1981-1990, 1991-2000 and $2001-2009$ were $1.33 \%, 1.11 \%$ and $2.08 \%$ respectively. In Indian agriculture we observed no change in different components of TFP, i.e., technical, scale and mix efficiency along with residual scale and mix efficiency remain unchanged during the periods under consideration.

In Nepal TFP growth rate was only $0.06 \%$ p.a., which is lowest in the region. During the first decade under consideration Nepalese agriculture grew at an impressive rate of $2.29 \%$ p.a. However, in the following decade it was reduced to only $0.25 \%$ p.a., which picked up a negative trend during 2001-2013 and estimated to be $-1.11 \%$ p.a. Fuglie [52] estimated annual agricultural TFP growth rate for Nepal for the periods $1981-1990$ and $1991-2000$ to be $2.34 \%$ and $0.19 \%$ p.a., respectively. There exists notable variation in TFP growth rate during the beginning of the century. Contrary to our negative growth rate $-1.11 \%$ p.a. for the period 2001-2013, Fuglie [52] estimated $2.49 \%$ annual growth rate during 2001-2009. During the period under consideration technical, scale and mix efficiency remained unchanged, whereas both residual and mix efficiency decreased @- $0.39 \%$ p.a. The only country specific research that could be accessed for Nepal estimated that TFP growth rate for the country's crop sector for the periods $1961-1980$ and $1981-2001$ were $0.20 \%$ and $2.42 \%$ p.a. [51]. 
Table 6. Changes in Total factor productivity (TFP) and its components for the selected years and over periods.

\begin{tabular}{|c|c|c|c|c|c|c|c|c|c|}
\hline Country & Period & TFP Change & $\begin{array}{l}\text { Maximum } \\
\text { TFP Change }\end{array}$ & $\begin{array}{l}\text { TFP Efficiency } \\
\text { Change }\end{array}$ & $\begin{array}{c}\text { Technical } \\
\text { Efficiency Change }\end{array}$ & $\begin{array}{l}\text { Scale Efficiency } \\
\text { Change }\end{array}$ & $\begin{array}{l}\text { Mix-Efficiency } \\
\text { Change }\end{array}$ & $\begin{array}{c}\text { Residual } \\
\text { Scale-Efficiency } \\
\text { Change }\end{array}$ & $\begin{array}{c}\text { Residual } \\
\text { Mix-Efficiency } \\
\text { Change }\end{array}$ \\
\hline \multirow{14}{*}{ Bangladesh } & 1981 & 0.96 & 1.11 & 0.87 & 1.00 & 1.00 & 1.00 & 0.87 & 0.87 \\
\hline & 1986 & 0.93 & 1.18 & 0.79 & 1.00 & 1.00 & 1.00 & 0.79 & 0.79 \\
\hline & 1991 & 0.90 & 1.18 & 0.77 & 1.00 & 1.00 & 1.00 & 0.77 & 0.77 \\
\hline & 1996 & 0.90 & 1.18 & 0.77 & 1.00 & 1.00 & 1.00 & 0.77 & 0.77 \\
\hline & 2001 & 1.04 & 1.18 & 0.88 & 1.00 & 1.00 & 0.99 & 0.89 & 0.88 \\
\hline & 2006 & 1.08 & 1.18 & 0.92 & 1.00 & 1.00 & 1.00 & 0.92 & 0.92 \\
\hline & 2010 & 1.37 & 1.18 & 1.17 & 1.00 & 1.00 & 1.00 & 1.17 & 1.17 \\
\hline & 2011 & 1.37 & 1.18 & 1.17 & 1.00 & 1.00 & 1.00 & 1.17 & 1.17 \\
\hline & 2012 & 1.40 & 1.18 & 1.19 & 1.00 & 1.00 & 1.00 & 1.19 & 1.19 \\
\hline & 2013 & 1.36 & 1.18 & 1.15 & 1.00 & 1.00 & 1.00 & 1.15 & 1.15 \\
\hline & $1981-1990$ & -0.60 & 0.69 & -1.02 & 0.00 & 0.01 & 0.00 & -1.02 & -1.02 \\
\hline & 1991-2000 & 1.71 & 0.00 & 1.45 & 0.00 & 0.00 & 0.00 & 1.45 & 1.45 \\
\hline & 2001-2013 & 2.44 & 0.01 & 2.06 & 0.00 & 0.00 & 0.09 & 1.98 & 2.06 \\
\hline & Whole period & 1.05 & 0.52 & 0.44 & 0.00 & 0.00 & 0.00 & 0.44 & 0.44 \\
\hline \multirow{10}{*}{ India } & 1981 & 1.11 & 1.11 & 1.00 & 1.00 & 1.00 & 1.00 & 1.00 & 1.00 \\
\hline & 1986 & 1.07 & 1.18 & 0.91 & 1.00 & 1.00 & 1.00 & 0.92 & 0.91 \\
\hline & 1991 & 1.12 & 1.18 & 0.95 & 1.00 & 1.00 & 1.00 & 0.95 & 0.95 \\
\hline & 1996 & 1.16 & 1.18 & 0.99 & 1.00 & 1.00 & 1.00 & 0.99 & 0.99 \\
\hline & 2001 & 1.07 & 1.18 & 0.91 & 1.00 & 1.00 & 0.98 & 0.93 & 0.91 \\
\hline & 2006 & 1.04 & 1.18 & 0.88 & 1.00 & 1.00 & 1.00 & 0.88 & 0.88 \\
\hline & $1981-1990$ & 0.17 & 0.69 & -0.44 & 0.00 & 0.00 & -0.23 & -0.22 & -0.44 \\
\hline & $1991-2000$ & -0.60 & 0.00 & -0.51 & 0.00 & 0.00 & -0.22 & -0.31 & -0.51 \\
\hline & $2001-2013$ & 0.85 & 0.01 & 0.71 & 0.00 & 0.00 & 0.18 & 0.54 & 0.71 \\
\hline & Whole period & 0.52 & 0.52 & 0.00 & 0.00 & 0.00 & 0.00 & 0.00 & 0.00 \\
\hline \multirow{14}{*}{ Nepal } & 1981 & 1.01 & 1.11 & 0.91 & 1.00 & 1.00 & 1.00 & 0.91 & 0.91 \\
\hline & 1986 & 0.98 & 1.18 & 0.83 & 1.00 & 1.00 & 0.96 & 0.87 & 0.83 \\
\hline & 1991 & 1.16 & 1.18 & 0.99 & 1.00 & 1.00 & 1.00 & 0.99 & 0.99 \\
\hline & 1996 & 1.23 & 1.18 & 1.05 & 1.00 & 1.00 & 1.00 & 1.05 & 1.05 \\
\hline & 2001 & 1.17 & 1.18 & 0.99 & 1.00 & 1.00 & 1.00 & 0.99 & 0.99 \\
\hline & 2006 & 1.09 & 1.18 & 0.93 & 1.00 & 1.00 & 1.00 & 0.93 & 0.93 \\
\hline & 2010 & 1.02 & 1.18 & 0.86 & 1.00 & 1.00 & 1.00 & 0.86 & 0.86 \\
\hline & 2011 & 1.09 & 1.18 & 0.92 & 1.00 & 1.00 & 1.00 & 0.92 & 0.92 \\
\hline & 2012 & 1.15 & 1.18 & 0.98 & 1.00 & 1.00 & 1.00 & 0.98 & 0.98 \\
\hline & 2013 & 1.02 & 1.18 & 0.87 & 1.00 & 1.00 & 1.00 & 0.87 & 0.87 \\
\hline & 1981-1990 & 2.29 & 0.69 & 1.41 & 0.00 & 0.00 & 0.00 & 1.41 & 1.41 \\
\hline & 1991-2000 & 0.25 & 0.00 & 0.21 & 0.00 & 0.00 & 0.48 & -0.28 & 0.21 \\
\hline & 2001-2013 & -1.11 & 0.01 & -0.96 & 0.00 & 0.00 & 0.00 & -0.96 & -0.96 \\
\hline & Whole period & 0.06 & 0.52 & -0.39 & 0.00 & 0.00 & 0.00 & -0.39 & -0.39 \\
\hline
\end{tabular}


Table 6. Cont.

\begin{tabular}{|c|c|c|c|c|c|c|c|c|c|}
\hline Country & Period & TFP Change & $\begin{array}{l}\text { Maximum } \\
\text { TFP Change }\end{array}$ & $\begin{array}{l}\text { TFP Efficiency } \\
\text { Change }\end{array}$ & $\begin{array}{c}\text { Technical } \\
\text { Efficiency Change }\end{array}$ & $\begin{array}{l}\text { Scale Efficiency } \\
\text { Change }\end{array}$ & $\begin{array}{l}\text { Mix-Efficiency } \\
\text { Change }\end{array}$ & $\begin{array}{c}\text { Residual } \\
\text { Scale-Efficiency } \\
\text { Change }\end{array}$ & $\begin{array}{c}\text { Residual } \\
\text { Mix-Efficiency } \\
\text { Change }\end{array}$ \\
\hline \multirow{14}{*}{ Pakistan } & 1981 & 1.01 & 1.11 & 0.91 & 1.00 & 1.00 & 1.00 & 0.91 & 0.91 \\
\hline & 1986 & 1.16 & 1.18 & 0.99 & 1.00 & 1.00 & 1.00 & 0.99 & 0.99 \\
\hline & 1991 & 1.16 & 1.18 & 0.99 & 1.00 & 1.00 & 1.00 & 0.99 & 0.99 \\
\hline & 1996 & 1.23 & 1.18 & 1.05 & 1.00 & 1.00 & 1.00 & 1.05 & 1.05 \\
\hline & 2001 & 1.10 & 1.18 & 0.94 & 0.94 & 0.99 & 0.95 & 1.05 & 1.00 \\
\hline & 2006 & 1.06 & 1.18 & 0.91 & 0.97 & 1.00 & 0.95 & 0.99 & 0.93 \\
\hline & 2010 & 1.02 & 1.18 & 0.87 & 0.98 & 1.00 & 0.92 & 0.97 & 0.89 \\
\hline & 2011 & 1.08 & 1.18 & 0.92 & 1.00 & 1.00 & 0.92 & 1.00 & 0.92 \\
\hline & 2012 & 1.03 & 1.18 & 0.87 & 1.00 & 1.00 & 0.84 & 1.04 & 0.87 \\
\hline & 2013 & 1.13 & 1.18 & 0.96 & 1.00 & 1.00 & 0.92 & 1.04 & 0.96 \\
\hline & 1981-1990 & 1.56 & 0.69 & 0.79 & 0.00 & 0.00 & 0.00 & 0.79 & 0.79 \\
\hline & $1991-2000$ & 0.80 & 0.00 & 0.68 & 0.00 & 0.00 & -0.05 & 0.73 & 0.68 \\
\hline & $2001-2013$ & 0.18 & 0.01 & 0.15 & 0.44 & 0.05 & -0.19 & -0.09 & -0.29 \\
\hline & Whole period & 0.38 & 0.52 & -0.12 & 0.00 & 0.00 & -0.23 & 0.12 & -0.12 \\
\hline
\end{tabular}


The annual TFP growth rate for Pakistan is estimated to be $0.38 \%$ p.a. Pakistan has similar decreasing pattern as Nepal, though did not experience negative growth rate. During 1981-1990, Pakistan's agriculture grew at a rate of $1.56 \%$ p.a., which later reduced to $0.80 \%$ and $0.18 \%$ during 1991-2000 and 2001-2013 respectively. Fuglie estimated TFP growth rate for Pakistan to be $3.21 \%$, $1.19 \%$ and $0.59 \%$ p.a. for the periods $1981-1990,1991-2000$ and 2001-2009 respectively [52]. Through the Cobb-Douglas specification Chowdhury [78] estimated that over the period 1990-05 the annual TFP growth rate for Pakistan agriculture was $1.75 \%$. This outcome is almost the same as Martin and Mitra's estimates of $1.70 \%$ p.a. using the Cobb-Douglas model for the period from 1967 to 1992. However, their estimated translog form showed a productivity growth of $2.30 \%$ p.a. for the same period [79]. Khan [80] noted that Pakistan agricultural TFP grew at a rate of 2.1\% p.a. for the period from 1980 to 1993, which is higher than those of Khan [81] and Kemal et al [82], whose findings were $0.90 \%$ (for the period 1960-1996) and 0.37\% (for the period 1965-2001). In Pakistan, we found both technical and scale efficiency remain unchanged, though mix efficiency reduced by $-0.23 \%$ p.a. The residual scale efficiency grew at $0.12 \%$ p.a., whereas the residual mix efficiency decreased by the same proportion.

\subsection{Determinants of TFP Changes}

Table 7 presents the parameter estimates of the Dynamic difference GMM model to identify the determinants of agricultural TFP change in South Asian region using Equation (13). Several hypothesis tests were conducted to confirm validity of the model. The test results are presented at the lower panel of Table 7 First, is the Sargan test of over-identification restriction, which tests whether the 'instruments as a group are exogenous' [71]. According to the estimated $p$-value of the test, the null-hypothesis cannot be rejected and hence the instruments as the group are exogenous or not endogenous. According to Bingxing et al. the GMM estimator is consistent only if there is no second-order serial correlation in the idiosyncratic error term of the first-difference equations [66]. To identify serial correlation, Arellano and Bond [72] developed a z-test. A significant negative first-order autocorrelation followed by a no second-order autocorrelation in differenced residuals imply that the disturbances are not serially correlated, which is certainly our case. Hence with strong evidence we can argue for the consistency of our GMM estimators. Two tests were conducted to test the exogeneity of the used instruments. One tests the exogeneity of GMM instruments for levels, whereas the other has the null hypothesis of exogeniety of IV instruments. Both the test statistics were insignificant, as required for validity of the used instruments. Furthermore, failure to reject the null-hypothesis of exogeniety of IV instruments imply that the data used are consistent and satisfy all the moments conditions and therefore the instrumental variables used also assumed to satisfy the exclusion restrictions. The Wald $\chi^{2} \mathrm{~F}$-statisticwhich tests the null that 'the coefficients on the explanatory variables are jointly zero' is strongly rejected at $1 \%$ level of significance, there by justifying inclusion of the variables to explain change in TFP index value (Table 7).

Table 7. Dynamic (difference) GMM estimator for the determinants total factor productivity change.

\begin{tabular}{ccc}
\hline Variables & Coefficients & Std. Err. \\
\hline Constant & $0.1278^{\mathrm{ns}}$ & 0.1132 \\
Lagged change in TFP ( $\mathrm{t}-1$ year) & $0.7072^{* * *}$ & 0.0651 \\
Technology capital & $0.3775^{* *}$ & 0.1846 \\
Mechanization level & $-0.0019^{\mathrm{ns}}$ & 0.0055 \\
Human capital & $0.0104^{*}$ & 0.0058 \\
Financial capital & $-0.2887^{* *}$ & 0.0918 \\
Natural capital & $1.0522^{* *}$ & 0.4364 \\
Herfindahl index of crop diversification & $0.1720^{* *}$ & 0.0870 \\
\hline
\end{tabular}


Table 7. Cont.

\begin{tabular}{ccc}
\hline Variables & Coefficients & Std. Err. \\
\hline Model diagnostics & \\
Wald $\chi^{2}$ & $265.74^{* * *}$ \\
Sargan test of overid. Restrictions $\left(\chi^{2} 124\right)$ & $117.74^{\mathrm{ns}}$ \\
Arellano-Bond test for AR(1) in first differences $(\mathrm{z}$-statistic) & $-5.68^{* * *}$ \\
Arellano-Bond test for AR(2) in first differences (z-statistic) & $0.39^{\mathrm{ns}}$ \\
Difference-in-Sargan's tests of exogeneity of instrument subsets: & \\
GMM instruments for levels (null: H = exogenous) $\left(\chi^{2} 4 \mathrm{df}\right)$ & $0.25^{\mathrm{ns}}$ \\
IV instruments (null: H = exogenous) $\left(\chi^{2} 2 \mathrm{df}\right)$ & $-0.00^{\mathrm{ns}}$ \\
Number of observations & $132^{2}$ \\
\hline
\end{tabular}

Note: Instruments for first differences equation: Standard D. (natural capital, human capital); GMM-type (missing $=0$, separate instruments for each period unless collapsed); L(1/.) (L.chtfp technology capital, mechanization level, Herfindahl index of crop diversification, financial capital). ${ }^{*}, * *$ and ${ }^{* * *}$ indicate significant at $10 \%, 5 \%$ and $1 \%$ levels, respectively. ${ }^{\text {ns }}$ means not significant.

The associated sign with the estimated coefficient of the natural capital variable implies that an increase in per capita arable land positively contributes to TFP change. Availability of land may allow more diversified farming, particularly allowing shifting from low value added cereals to high value added cash crops. Most literature argued for efficiency and growth enhancing role of land availability, particularly in land scarce countries [17,83-85]; with a few exception [86].

In most of the existing literature, research was identified as a crucial factor for accelerating TFP growth (e.g., [17,46,51,87-89]). We have adopted Avila and Evenson's concept to construct technology capital and mechanization level variables [51]. Kumar [89] estimated that in India research accounts for $20.0 \%, 54.5 \%, 26.6 \%$ and $57.9 \%$ growth in rice, wheat, sorghum and maize, respectively. Rosegrant and Evenson [87] estimated that public research alone can explain more than $30 \%$ of TFP growth in India. We also found significant effect of technology capital on TFP growth for South Asia, which conforms with the literature. However, we did not find significant influence of the mechanization level on TFP growth. The reason may be due to the fact that the level of mechanization of agricultural sector is still quite low and traditionally confined to irrigation equipment since the introduction of the GR technology during the 1960s. Mechanization in land preparation is becoming prominent only in the recent decades due to shortage of the conventional draft power services used for such operations in South Asia.

The variable financial capital has negative sign in the model. The negative sign here implies that with increasing development flow and share of agricultural credit to total credit, TFP declines. Development flows from donors were made with a thrust to reduce gap between desired and actual domestic investments. In the process, it is expected to have manifold contribution, of which the ultimate focus is economic growth through employment creation and poverty reduction [90-92]. Past TFP performances is another crucial factor for TFP growth. This is evident from the significantly positive coefficient of the lag of TFP change.

Human capital, measured as average year of schooling is positively associated with TFP change. It is generally believed that, education positively contributes in farming activities [93], and a bulk volume of literature concluded with growth and efficiency enhancing role of education [94-97]. However, an exception exists where education is found to have alternative role. For instance, though Rahman and Salim [17] observed that during 1948-2008 in Bangladesh, literacy significantly contributed to technical change, but worked against technical and scale-efficiency changes and TFP growth. Deb [98] reported the growth reducing role of education in Bangladesh. Pritchett's cross country analysis [99] showed no association between the increases in educational attainment and the rate of growth of output per worker, whereas educational capital and TFP were negatively and significantly associated. 
Level of crop diversification, measured through Herfindahl index, negatively contributes in TFP growth. Use of Herfindahl index in estimating level of crop diversification is common in the literature $[17,100,101]$. Crop diversification is a commonly prescribed strategy in different policy documents for agricultural growth and development. Much of the literature observed positive impact of crop diversification on farm income [102,103], as well as on technical efficiency [104] and agricultural growth [105]. Contrary to these, Llewelyn and Williams [106] observed that in Indonesia crop diversification significantly reduced technical efficiency. In Ethiopia the diversified farms operate at relatively lower level of allocative and economic efficiency [107].

\section{Discussion}

Growth in agricultural TFP is desirable as this indicates that the sector is able to enhance its productive capacity while economizing on the use of scarce resources and able to reap the benefit of the investments in technology and infrastructures. However, it is also important to identify the components contributing to agricultural TFP growth so that one can pinpoint the sources of observed growth. For example, the almost unitary technical efficiency scores for the four countries under study imply that farmers in these countries are already operating at their technical best, and therefore, scope to increase physical output is limited. Furthermore, the estimated scale and mix efficiency scores indicates that the countries are performing well and are able to derive economies of scale by adjusting input and output mixes subject to existing technology level $[49,67]$. However, there is substantial scope to improve residual scale efficiency and residual mix-efficiency levels, particularly in Bangladesh and Nepal. This indicates that the countries can improve their productivity by changing input and output mixes as well as scale of operation [17].

The prominent role of capitals in driving agricultural TFP growth provides clue to improve the sector by undertaking appropriate actions. For example, the significant role of natural, technology and human capitals in driving observed agricultural TFP growth in these countries provide confidence that effective utilization of existing land resource base and investments in technology development and education is a right path to follow. It is also clear that crop concentration, mainly cereals, has driven agricultural TFP in these countries which points towards further widespread diffusion of the GR technology.

In the agrarian sector, literature argue for specific impacts such as productivity gain and poverty reduction [108]. Another school of thought is concerned with host country's lack of absorbing capacity (level of human capital, technology, infrastructure, and financial market structure, etc.), which may hinder yielding desired benefit from development flows [92]. Furthermore, acknowledging farmer's financial constraint as a core problem for technology adoption, agricultural credit was generally disbursed at subsidized interest rates. However, credit alone may not be the solution for agrarian transformation. For increasing production, along with improved inputs, knowledge and skills to use these inputs are important [108]. Farmers in the traditional cereal based economy may lack these knowledge and skills. Taylor et al. [109] provided empirical evidence that in Brazilian agricultural credit do not contribute to technical efficiency gain and has a slightly negative effect on allocative efficiency. Hence credit alone may not be a solution, particularly in a situation where the research-extension system is not effective.

\section{Conclusions and Policy Implications}

The present study assesses the sustainability of South Asian agriculture by computing multi-lateral multi-period TFP indices for a 34-year period (1980-2013). The study then decomposes the computed TFP index into six finer components (i.e., technical change, technical-, scale- and mix-efficiency changes, residual scale- and residual mix-efficiency changes). The study also examines the role of capital in driving agricultural productivity growth in South Asia. Results reveal that all countries sustained agricultural productivity growth but at variable rates. Bangladesh recorded the highest annual TFP growth rate estimated at $1.05 \%$, followed by India $(0.52 \%)$, Pakistan $(0.38 \%)$ and Nepal 
$(0.06 \%)$, respectively. During the period, the countries experienced little or no variation in technical, scale and mix efficiency changes, but differential changes were observed for residual scale and mix efficiency changes amongst countries which are largely responsible for differential rate of TFP growth. For Bangladesh, both residual scale and mix efficiency increased by $0.44 \%$ p.a. In India, both these components were unchanged, whereas in Nepal, both components were reduced by $-0.39 \%$ p.a. In Pakistan, residual scale efficiency increased by $0.12 \%$ p.a., whereas the mix efficiency decreased by the same rate. The major drivers for the TFP growth are natural and technology capital. Financial capital and crop diversification retards TFP growth.

Based on the results of the study, several interventions can be offered. First, land reform and tenurial policies aimed at consolidating farm size and smooth functioning of the land rental market are important as these measure will improve natural capital. Given the nature of land scarcity of these South Asian countries, effective implementation and modernization of tenurial policies will have more discernible impact on enhancing access to natural capital by large masses of landless farming population who will then be able to enter farming and will thus contribute towards agricultural productivity growth. Rahman and Salim also noted land reform measures aimed at consolidating average farm operation size to improve productivity in Bangladesh agriculture [17]. Second, investment in agricultural R\&D aimed at improving production technologies and modernization of farming will contribute significantly to agricultural productivity growth in South Asia. Rahman and Salim also recommended investments in R\&D in Bangladesh because of its prominent role in improving agricultural productivity [17]. Investment in education is another crucial factor, which will not only boost agricultural growth, but also has several folds of benefits through developing human capital. However, interventions related to education should target unfavorable institutional/governance environment that hinder attainable outcomes of education, as suggested by Pritchett [99]. Keeping in mind the average year of schooling in the south Asian countries, which is generally less than primary level (Table 4), government should invest more in primary and technical education. However, the tertiary level education should not be overlooked, as investment here is required for technological breakthrough.

The negative association between crop diversification and TFP growth does not necessarily argue for cereal based specialized farming system. Rather it argues for further research to explore farm level inefficiency and marketing constraints that farmers face while producing non-cereal cash crops. Extension activities are another important component necessary to create enabling environment so that farmers can yield desired benefit of crop diversification. In addition, further diffusion of GR technology is also desirable.

The welfare implication of our study is as follows: it was established in the introduction section that agricultural growth through the attainment of higher level of TFP is one of the major policy objectives of South Asian economies. However, in the pursuit of economic development, optimization among different goals (e.g., industrialization and service sector growth) can be problematic because it only targets higher economic growth, while neglecting the agricultural sector, does not necessarily imply welfare for all of the population, particularly the poor, and ultimately increases inequality. For example, Alesina and Rodrik [110] observed that growth maximizing policies are optimal only for governments concerned with the capitalist class. Concerns about economic growth and its redistributive effect are well documented in the economic literature [111-113]. Therefore, we argue that, for the desired growth to benefit all segments of the population, particularly the rural poor, agricultural sector growth should be included within wider range of optimization concerns of a country, particularly focusing on the dimensions of sustainability and welfare issues. Finally, we recommend a detailed study incorporating biophysical dimension along with different economic and social aspects of TFP. Here it is noteworthy to mention that while examining the impacts of prices, resources, technology, education, public investments, climatic variables and agroecology on long-term food availability in Bangladesh, Rahman found climatic and agroecological factors to have relatively more influence on food availability than GR technologies [114]. 
Author Contributions: Asif Reza Anik and Sanzidur Rahman conceived the main method, designed the main stages in the research. Asif Reza Anik collected the necessary data, where Sanzidur Rahman and Jaba Rani Sarker supplemented. Asif Reza Anik conducted the data analysis. Sanzidur Rahman supervised the data collection and analysis process. Asif Reza Anik wrote the paper. Sanzidur Rahman modified and improved the paper. Jaba Rani Sarker contributed in literature search and write-up.

Conflicts of Interest: The authors declare no conflict of interest.

\section{References}

1. SAARC Secretariat. Best Practices in Poverty Alleviation and SDGs in South Asia: A Compendium; SAARC Secretariat: Kathmandu, Nepal, 2014.

2. Ministry of Finance of the People's Republic of Bangladesh. Bangladesh Economic Review 2014; Ministry of Finance: Dhaka, Bangladesh, 2015.

3. National Statistics Bureau of the Royal Government of Bhutan. Statistical Year Book of Bhutan 2015; Kunesel Cooperation Ltd.: Thimphu, Bhutan, 2015.

4. Ministry of Finance of the Government of India. India Economic Survey 2014-15; Ministry of Finance: Delhi, India, 2016.

5. Ministry of Finance, Economic Affairs, Revenue, Statistics \& Privatization of the Government of Pakistan. Year Book 2014-15; Statistics Division: Islamabad, Pakistan, 2015.

6. Ministry of Agricultural Development of the Government of Nepal. Statistical Information on Nepalese Agriculture 2012/2013; Agri-Business Promotion and Statistics Division: Kathmundu, Nepal, 2013.

7. International Labour Organization. Key Indicators of the Labour Market Database; International Labour Organization: Rome, Italy, 2015.

8. Central Bureau of Statistics of the Central Bank of Sri Lanka. Economic and Social Statistics of Sri Lanka 2014; Statistics Department: Colombo, Sri Lanka, 2015.

9. Planning Commission of India (PCI). Twelfth Five Year Plan (2012-2017) Economic Sectors; Planning Commission, Government of India: Delhi, Indian, 2013.

10. Planning Commission of Pakistan (PCP). Eleventh Five Year Plan (2013-2018); Ministry of Planning, Development and Reform, Government of Pakistan: Islamabad, Pakistan, 2014.

11. National Planning Commission of Nepal (NPCN). An Approach Paper to the Thirteenth Plan (FY 2013/14-2015/16); National Planning Commission, Government of Nepal: Kathmandu, Nepal, 2013.

12. Ministry of Agricultural Development Nepal (MoADN). Agricultural Development Strategy (ADS) 2014; Government of Nepal: Kathmundu, Nepal, 2014.

13. General Economic Division (GED). 7th Five Year Plan FY 2016-FY 2020 Accelerating Growth, Empowering Citizens; Planning Commission, Ministry of Planning, Government of Bangladesh: Dhaka, Bangladesh, 2015.

14. FAOSTAT. Food and Agriculture Organization of the United Nations. Statistical Database. 2016. Available online: http:/ / www.fao.org/faostat/en/ (accessed on 12 March 2017).

15. Byerlee, D. Technical Change, Productivity, and Sustainability in Irrigated Cropping Systems of South Asia: Emerging Issues in the Post-Green Revolution ERA. J. Int. Dev. 1992, 4, 477-496. [CrossRef]

16. Joshi, P.K.; Joshi, L.; Singh, R.K.; Thakur, J.; Singh, K.; Giri, A.K. Analysis of Productivity Changes and Future Sources of Growth for Sustaining Rice-Wheat Cropping System; National Agricultural Technology Project (PSR 15; 4.2); National Centre for Agricultural Economics and Policy Research (NCAP): New Delhi, India, 2003.

17. Rahman, S.; Salim, R. Six Decades of Total Factor Productivity Change and Sources of Growth in Bangladesh Agriculture (1948-2008). J. Agric. Econ. 2013, 64, 275-294. [CrossRef]

18. Planning Commission of the Government of the People's Republic of Bangladesh. Steps towards Change-National Strategy for Accelerated Poverty Reduction II; General Economic Division: Dhaka, Bangladesh, 2009.

19. Bera, A.K.; Kelly, T.G. Adoption of high yielding rice varieties in Bangladesh: An econometric analysis. J. Dev. Econ. 1990, 33, 263-285. [CrossRef]

20. O'Donnell, C.J. Measuring and decomposing agricultural productivity and profitability change. Aust. J. Agric. Resour. Econ. 2010, 54, 527-560. [CrossRef]

21. Ali, M.; Byerlee, D. Productivity Growth and Resource Degradation in Pakistan's Punjab: A Decomposition Analysis; Policy Research Working Paper No. 2480; World Bank: Washington, DC, USA, 2000. 
22. Sidhu, D.S.; Byerlee, D. Technical Change and Wheat Productivity in the Indian Punjab in the Post-Green Revolution Period; CIMMYT Economics Working Paper No. 92-02; CIMMYT: Mexico City, Mexico, 1992.

23. Cassman, K.G.; Pingali, P.L. Extrapolating trends from long-term experiments to farmers' fields: The case of irrigated rice systems in Asia. In Agricultural Sustainability: Economic, Environmental, and Statistical Considerations; Barnett, V., Payne, R., Steiner, R., Eds.; John Wiley \& Sons: London, UK, 1995; pp. 63-84.

24. Gordon, I.J.; Squire, G.; Prins, H.H.T. (Eds.) Food Production and Nature Conservation: Conflicts and Solutions; Routledge Press: New York, NY, USA, 2017.

25. O'Connell, P.F. Sustainable agriculture. In Agriculture and the Environment: The 1991 Yearbook of Agriculture; US Government Printing Office: Washington, DC, USA, 1991.

26. Millennium Ecosystem Assessment (MA). Ecosystems and Human Well-Being: Synthesis; World Resources Institute: Washington, DC, USA, 2005.

27. Pretty, J.N. Regenerating Agriculture: Policies and Practice for Sustainability and Self-Reliance; Earths can Publications Limited: London, UK, 1995.

28. Rosegrant, M.; Li, W.; Clein, S.A.; Sulser, T.; Valmonte-Santos, R. Looking Ahead: Long-Term Prospects for Africa's Agricultural Development and Food Security; International Food Policy Research Institute: Washington, DC, USA, 2005.

29. Delgado, C.; Rosegrant, M.; Steinfeld, H.; Ehui, S.; Courbois, C. Livestock to 2020: The Next Food Revolution; 2020 Vision Discussion Paper No. 28; International Food Policy Research Institute: Washington, DC, USA, 1999.

30. Cohen, J.E. Human population: The next half century. Science 2003, 302, 1172-1175. [CrossRef] [PubMed]

31. Sustainable Development Solutions Network. Solutions for Sustainable Agriculture and Food Systems; Technical Report for the Post-2015 Development Agenda; Sustainable Development Solutions Network: New York, NY, USA, 2013.

32. Scherr, S.J.; McNeely, J.A. Biodiversity Conservation and Agricultural Sustainability: Towards a New Paradigm of 'Ecoagriculture' Landscapes. Philos. Trans. Biol. Sci. 2008, 363, 477-494. [CrossRef] [PubMed]

33. Von Braun, J. Agricultural Growth, Environmental Degradation, Poverty, and Nutrition: Links and Policies; Zeitschrift fur auslaendische Landwirtschaft: Materialsammlung, Germany, 1992. (In Germany)

34. Grepperud, S. Poverty, land degradation and climatic uncertainty. Oxf. Econ. Pap. 1997, 49, 586-608. [CrossRef]

35. Herdt, R.W.; Lynam, J.K. Sustainable development and the changing needs of international agricultural research. In Assessing the Importance of International Agricultural Research for Sustainable Development; Lee, D.R., Kearl, S., Uphoff, N., Eds.; Cornell University Press: Ithaca, NY, USA, 1992.

36. Byerlee, D.; Murgai, R. Sense and sustainability revisited: The limits of total factor productivity measures of sustainable agricultural systems. Agric. Econ. 2001, 26, 227-236. [CrossRef]

37. Lynam, J.K.; Herdt, R.W. Sense and sustainability: Sustainability as an objective in international agricultural research. Agric. Econ. 1989, 3, 381-398. [CrossRef]

38. Mukherjee, A.N.; Kuroda, Y. Productivity growth in Indian agriculture: Is there evidence of convergence across states? Agric. Econ. 2003, 29, 43-53. [CrossRef]

39. Fan, S.; Hazell, P.; Thorat, S. Government spending, growth and poverty in rural India. Am. J. Agric. Econ. 2000, 82, 1038-1051. [CrossRef]

40. Ministry of Agriculture of the Government of India ACD. Agriculture Census 2010-11, All India Report on Number and Area of Operational Holdings; Agriculture Census Division: New Delhi, India, 2014.

41. Bangladesh Bureau of Statistics of the Government of People's Republic of Bangladesh. Agriculture Census 2008; Bangladesh Bureau of Statistics: Dhaka, Bangladesh, 2010.

42. Central Bureau of Statistics of the Government of Nepal. Statistical Pocket Book 2014; Central Bureau of Statistics: Kathmandu, Nepal, 2015.

43. Pakistan Bureau of Statistics. Pakistan Bureau of Statistics of the Government of Pakistan Agricultural Census 2010; Pakistan Bureau of Statistics: Islamabad, Pakistan, 2010.

44. Pingali, P.L. Green Revolution: Impacts, limits, and the path ahead. Proc. Natl. Acad. Sci. USA 2012, 109, 12302-12308. [CrossRef] [PubMed]

45. Kumar, P.; Mittal, S.; Hossain, M. Agricultural Growth Accounting and Total Factor Productivity in South Asia: A Review and Policy Implications. Agric. Econ. Res. Rev. 2008, 2008, 145-172. 
46. Coelli, T.J.; Rao, D.S.P. Total Factor Productivity Growth in Agriculture: A Malmquist Index Analysis of 93 Countries, 1980-2000. In Proceedings of the International Association of Agricultural Economics Conference, Durban, South Africa, 16-22 August 2003.

47. Shahabinejad, V.; Akbari, A. Measuring agricultural productivity growth in Developing Eight. J. Dev. Agric. Econ. 2010, 2, 326-332.

48. O'Donnell, C.J. Nonparametric estimates of the components of productivity and profitability change in US agriculture. Am. J. Agric. Econ. 2012, 94, 873-890. [CrossRef]

49. O'Donnell, C.J. An aggregate quantity-price framework for measuring and decomposing productivity and profitability change. J. Product. Anal. 2012, 38, 255-272. [CrossRef]

50. O'Donnell, C.J. Econometric estimation of distance functions and associated measures of productivity and efficiency change. J. Product. Anal. 2014, 41, 187-200.

51. Avila, A.F.D.; Evenson, R.E. Total Factor Productivity Growth in Agriculture: The Role of Technological Capital. In Handbook of Agricultural Economics; Pingali, P.L., Evenson, R.E., Eds.; Academic Press: Burlington, The Netherlands, 2010; pp. 3769-3822.

52. Fuglie, K.O. Productivity Growth in Agriculture: An International Perspective. In Productivity Growth and Technology Capital in the Global Agricultural Economy; Fuglie, K.O., Wang, S.L., Ball, V.E., Eds.; CAB International: Oxfordshire, UK, 2012.

53. Temoso, O.; Villano, R.A.; Hadley, D. Agricultural productivity, efficiency and growth in a semi-arid country: A case study of Botswana. Afr. J. Agric. Resour. Econ. 2015, 10, 192-206.

54. Fan, S.; Hazell, P.B.R.; Thorat, S. Linkages between Government Spending, Growth, and Poverty in Rural India; Research Report No. 110; International Food Policy Research Institute: Washington, DC, USA, 1999.

55. National Bureau of Statistics of the Republic of Maldives. Statistical Year Book of Maldives 2014; National Bureau of Statistics: Malé, Maldives, 2015.

56. Roder, W.; Dorji, K.; Gratzer, G. Nutrient flow from the forest-Source of life for traditional Bhutanese agriculture. Austrian J. For. Sci. 2003, 1, 65-72.

57. Gurung, T. Organic Farming in Bhutan. Bhutan: Ways of Knowing; Rennie, F., Mason, R., Eds.; Information Age Publishing Inc.: Charlotte, NC, USA, 2008; pp. 205-210.

58. Tobgay, S. Agriculture Diversification in Bhutan. In Proceedings of the International Association of Agricultural Economists Conference, Gold Coast, Australia, 12-18 August 2006.

59. Ministry of Agriculture of the Royal Government of Bhutan. National Framework for Organic Farming in Bhutan; Ministry of Agriculture: Thimphu, Bhutan, 2007.

60. Tshomo, K. Bhutan's Status on Development Strategy for Organic Sector. In Proceedings of the International Organic and Ecological Agriculture in Mountain ecosystems, Thimphu, Bhutan, 5-8 March 2014.

61. Bjurek, H. The Malmquist total factor productivity index. Scand. J. Econ. 1996, 98, 303-313. [CrossRef]

62. O'Donnell, C.J. DPIN 3.0: A Program for Decomposing Productivity Index Numbers; Centre for Efficiency and Productivity Analysis, University of Queensland: Brisbane, Australia, 2011.

63. Färe, R.; Primont, D. Multi-output Production and Duality: Theory and Applications; Kluwer Academic Publishers: Boston, MA, USA, 2005.

64. Coelli, T.J.; Rao, D.S.P.; O'Donnell, C.J.; Battese, G.E. An Introduction to Efficiency and Productivity Analysis; Springer: New York, NY, USA, 2005.

65. Shephard, R.W. Theory of Cost and Production Frontiers; Princeton University Press: Princeton, NJ, USA, 1970.

66. Yu, B.; Liu, F.; You, L. Dynamic Agricultural Supply Response under Economic Transformation: A Case Study of Henan, China. Am. J. Agric. Econ. 2011, 94, 370-376. [CrossRef]

67. Yanrui, W. Productivity growth, technological progress and technical efficiency change in China: A three-sector analysis. J. Comp. Econ. 1995, 21, 207-229.

68. Evenson, R.E.; Pray, C.; Rosegrant, M.W. Agricultural Research and Productivity Growth in India; Research Report No. 109; International Food Policy Research Institute: Washington, DC, USA, 1999.

69. Kumar, P.; Kumar, A.; Mittal, S. Total factor productivity of crop sector in the Indo-Gangetic Plain of India: Sustainability issues revisited. Indian Econ. Rev. 2004, 39, 169-201.

70. World Economic Forum. The Human Capital Report 2015: Employment, Skills and Human Capital Global Challenge Insight Report; World Economic Forum: Geneva, Switzerland, 2015.

71. Mileva, E. Using Allerano-Bond Dynamic Panel GMM Estimator in STATA; Economics Department, Fordham University: New York, NY, USA, 2007. 
72. Allerano, M.; Bond, S. Some tests of specification for panel data: Monte Carlo evidence and an application to employment equations. Rev. Econ. Stud. 1991, 58, 277-297.

73. Roodman, D. How to do xtabond2: An introduction to difference and system GMM in Stata. Stata J. 2009, 9 , 86-136. [CrossRef]

74. Pray, C.; Ahmed, Z. Research and agricultural productivity growth in Bangladesh. In Research and Productivity in Asian Agriculture; Evenson, R.E., Pray, C., Eds.; Cornell University Press: Ithaca, NY, USA, 1991.

75. Dey, M.; Evenson, R.E. The Economic Impact of Rice Research in Bangladesh; BRRI/IRRI/BARC: Dhaka, Bangladesh, 1991.

76. Coelli, T.; Rahman, S.; Thirtle, C. A stochastic frontier approach to total factor productivity measurement in Bangladesh crop agriculture, 1961-92. J. Int. Dev. 2003, 15, 321-333.

77. Rahman, S. Regional productivity and convergence in Bangladesh agriculture. J. Dev. Areas 2007, 41, 221-236.

78. Chaudhry, A.A. Total Factor Productivity Growth in Pakistan: An Analysis of the Agricultural and Manufacturing Sectors. Lahore J. Econ. 2009, 14, 1-16.

79. Martin, W.; Mitra, D. Productivity Growth and Convergence in Agriculture and Manufacturing; World Bank Working Paper Number 2171; World Bank: Washington, DC, USA, 1999.

80. Khan, M.H. The Structural Adjustment Process and Agricultural Change in Pakistan in the 1980s and 1990s. Pak. Dev. Rev. 1994, 33, 533-591.

81. Khan, M.H. Agricultural 'Crisis' in Pakistan: Some Explanations and Policy Options. Pak. Dev. Rev. 1997, 36, 419-459.

82. Kemal, A.R.; Din, M.; Qadir, U. Global Research Project: Pakistan Country Report; Pakistan Institute of Development Economics: Islamabad, Pakistan, 2002.

83. Lau, L.; Yotopulos, P. A test for relative efficiency and application to Indian agriculture. Am. Econ. Rev. 1971, 61, 94-109.

84. Cornia, G.A. Farm size, land yields and the agricultural production function: An analysis for fifteen developing countries. World Dev. 1985, 13, 513-534. [CrossRef]

85. Carroll, J.; Newman, C.; Thorne, F. A comparison of stochastic frontier approaches for estimating technical inefficiency and total factor productivity. Appl. Econ. 2011, 43, 4007-4019. [CrossRef]

86. Zhou, L.; Zhang, H. Productivity Growth in China's Agriculture during 1985-2010. J. Integr. Agric. 2013, 12, 1896-1904.

87. Rosegrant, M.W.; Evenson, R.E. Agricultural Productivity and Sources of Growth in South Asia. Am. J. Agric. Econ. 1992, 74, 757-761. [CrossRef]

88. Rosegrant, M.W.; Evenson, R.E.; Mahmood, M. Agricultural Productivity Growth in Pakistan and India: A Comparative Analysis. Pak. Dev. Rev. 1993, 32, 433-451.

89. Kumar, P. Agricultural performance and productivity. In Indian Agricultural Policy at the Crossroads; Acharya, S.S., Chaudhri, D.P., Eds.; Rawat Publications: New Delhi, India, 2001; pp. 353-476.

90. Blomström, M.; Kokko, A. The Economics of Foreign Direct Investment Incentives; NBER Working Paper No. 9489; National Bureau of Economic Research: Cambridge, MA, USA, 2003.

91. Klein, M.; Aaron, C.; Hadjimichael, B. Foreign Direct Investment and Poverty Reduction; World Bank: Washington, DC, USA, 2003.

92. Borenzstein, E.; Gregorio, J.D.; Lee, J.W. How does Foreign Direct Investment Affect Economic Growth? J. Int. Econ. 1998, 45, 115-135.

93. Asadullah, M.N.; Rahman, S. Farm Productivity and Efficiency in Rural Bangladesh: The Role of Education Revisited. Appl. Econ. 2009, 41, 17-33. [CrossRef]

94. Belbase, K.; Grabowski, R. Technical Efficiency in Nepalese Agriculture. J. Dev. Areas 1985, 19, 515-526.

95. Ali, M.; Flinn, J.C. Profit efficiency among Basmati rice producers in Pakistan Punjab. Am. J. Agric. Econ. 1985, 71, 303-310. [CrossRef]

96. Wang, J.; Cramer, G.L.; Wailes, E.J. Production Efficiency in Chinese Agriculture: Evidence from Rural Household Survey Data. Agric. Econ. 1996, 15, 17-28. [CrossRef]

97. Seyoum, E.T.; Battese, G.E.; Fleming, E.M. Technical Efficiency and Productivity of Maize Producers in Eastern Ethiopia: A Study of Farmers within and Outside the Sasakawa-Global 2000 Project. Agric. Econ. 1998, 19, 341-348. [CrossRef]

98. Deb, U.K. Human Capital and Agricultural Growth in Bangladesh. Ph.D. Thesis, University of the Philippines at Los Banos, Los Banos, Philippines, 1995. 
99. Pritchett, L. Where has all the education gone? World Bank Econ. Rev. 2001, 15, 367-391. [CrossRef]

100. Bradshaw, B. Questioning crop diversification as a response to agricultural deregulation in Saskatchewan. Can. J. Rural Stud. 2004, 20, 35-48. [CrossRef]

101. Rahman, S. Six decades of agricultural land use change in Bangladesh: Effects on crop diversity, productivity, food availability and the environment, 1948-2006. Singap. J. Trop. Geogr. 2010, 31, 254-269. [CrossRef]

102. Kar, G.; Singh, R.; Verma, H.N. Alternative cropping strategies for assured and efficient crop production in upland rainfed rice areas of eastern India based on rainfall analysis. Agric. Water Manag. 2004, 67, 47-62. [CrossRef]

103. Van den Berg, M.M.; Hengsdijk, H.; Wolf, J.; Ittersum, M.K.V.; Guanghuo, W.; Roetter, R.P. The impact of increasing farm size and mechanization on rural income and rice production in Zhejiang province, China. Agric. Syst. 2007, 94, 841-850. [CrossRef]

104. Coelli, T.J.; Fleming, E. Diversification economies and specialization efficiencies in a mixed food and coffee smallholder farming system in Papua New Guinea. Agric. Econ. 2004, 31, 229-239. [CrossRef]

105. Rahman, S. Whether crop diversification is a desired strategy for agricultural growth in Bangladesh. Food Policy 2009, 34, 340-349. [CrossRef]

106. Llewelyn, R.V.; Williams, J.R. Nonparametric analysis of technical, pure technical, and scale efficiencies for food crop production in East java, Indonesia. Agric. Econ. 1996, 15, 113-126. [CrossRef]

107. Haji, J. Production efficiency of smallholders' vegetable-dominated mixed farming system in Eastern Ethiopia: A non-parametric approach. J. Afr. Econ. 2007, 16, 1-27. [CrossRef]

108. Steitieh, A.M. Input Productivity and Productivity Change of Crop Enterprise in Southern Brazil. Ph.D. Thesis, Ohio State University, Columbus, OH, USA, 1971.

109. Taylor, T.G.; Drummond, H.E.; Gomes, A.T. Agricultural Credit Programs and Production Efficiency: An Analysis of Traditional Farming in Southeastern Minas Gerais, Brazil. Am. J. Agric. Econ. 1986, 68, 110-119. [CrossRef]

110. Alesina, A.; Rodrik, D. Distributive politics and economic growth. Q. J. Econ. 1994, 109, 465-490. [CrossRef]

111. Paul, G.S.; Verdier, T. Inequality, redistribution and growth: A challenge to the conventional political economy approach. Eur. Econ. Rev. 1996, 40, 719-728. [CrossRef]

112. Aghion, P.; Caroli, E.; García-Peñalosa, C. Inequality and Economic Growth: The Perspective of the New Growth Theories. J. Econ. Lit. 1999, 37, 1615-1660. [CrossRef]

113. Midgley, J. Growth, Redistribution, and Welfare: Toward Social Investment. Soc. Serv. Rev. 1999, 73, 3-21. [CrossRef]

114. Rahman, S. Climate, Agroecology and Socio-Economic Determinants of Food Availability from Agriculture in Bangladesh (1948-2008). Sustainability 2017, 9, 354. [CrossRef] 